Article

\title{
Transformative Grassroots Leadership: Understanding the Role of Rojiroti's Women Leaders in Supporting Social Change
}

\author{
Rebecca Gordon ${ }^{1,2}$ \\ ${ }^{1}$ International Development Department, University of Birmingham, Birmingham, B152TT, UK; \\ E-Mail: r.l.gordon@bham.ac.uk \\ 2 Faculty of Education, University of Cambridge, Cambridge CB2 8PQ, UK
}

Submitted: 10 August 2020 | Accepted: 23 October 2020 | Published: 25 November 2020

\begin{abstract}
Many have argued that supporting women's leadership is an important pathway to women's empowerment. However, there is still a need for better understanding of how women become leaders, particularly at the grassroots level, and how they support social change. This article explores women's leadership as part of a grassroots microfinance organisation, Rojiroti. Through interviews and focus group discussions, it finds that Rojiroti's women leaders were motivated to become leaders to create better opportunities for their families and communities, and that they lead in line with frameworks of transformative leadership by supporting relationship building, by facilitating and guiding knowledge transfer and by providing space for reflection and skills for action (Wakefield, 2017). In particular, their situated knowledge was essential for inspiring shared vision for challenging unequal power relations. Overall, better understanding their leadership, that particularly nurtures relationships and collaboration, due to their position as being from the social groups they sought to support, is critical to the current challenges facing interventions and activism that seek to promote women's empowerment and contribute to social change.
\end{abstract}

\section{Keywords}

gender; grassroots; India; inequality; leadership; power relations; Rojiroti; social change

\section{Issue}

This article is part of the issue "Leadership and Political Change in Asia-Pacific" edited by David Hudson (University of Birmingham, UK), Nicolas Lemay-Hébert (Australian National University, Australia), Claire Mcloughlin (University of Birmingham, UK) and Chris Roche (La Trobe University, Australia).

(C) 2020 by the author; licensee Cogitatio (Lisbon, Portugal). This article is licensed under a Creative Commons Attribution 4.0 International License (CC BY).

\section{Introduction}

Effective women's leadership has often been associated with processes to challenge gender inequality and as such is closely linked with theories of empowerment. These theories have emphasised the role of women as active agents of social change (Jenkins, 2011). It has been argued that women's collective power and leadership are clear and necessary pathways to women's empowerment, and to inclusive and sustainable development (Esquivel \& Sweetman, 2016). However, although it is rooted in feminist activism and theory, there have been critiques of the concept of 'empowerment' as having led to an instrumental and depoliticised approach which has become "diffused and diluted" (Batliwala,
2007 , p. 559). Scholars have argued that research into women's empowerment needs to focus on political contention and engage with power relations that lead to inequality. In line with this, current understandings of empowerment specify the development of consciousness, and direct exercise of power, to achieve change (Nazneen, Hossain, \& Chopra, 2019). This brings us back to leadership since it is often essential for raising consciousness and disrupting existing unequal power structures. Batliwala's (2010) seminal work has emphasised the need to better understand leadership, particularly in the context of social justice. An understanding of where leaders come from, and how they advocate for reforms that disrupt discrimination, is important for considering how social change can be supported. 
Microfinance has been considered by many as an approach to promoting women's empowerment (Pokhriyal, Rani, \& Uniyal, 2014); however, it has also been widely criticised for being an example of where the concept of 'empowerment' has become depoliticised. For example, Kabeer $(2005$, p. 1) argued that microfinance is no "magic bullet" for women's empowerment if it does not address the constraints on women's agency posed by structural inequality. Indeed, giving money to women and encouraging productive activities has led to increasing pressure on women, rather than challenging underlying norms (Chant, 2016). Wilson (2015) powerfully argued that the poorest women are often excluded from microfinance groups, and those that are included are faced with increasing debts, whilst practices of solidarity are replaced with individualised and neoliberalised cultures, which perpetuate unequal power relations within communities.

It is clear then that many microfinance organisations do not support women's empowerment. However, previous research with a grassroots microfinance organisation in rural India, Rojiroti, found that it operated differently compared to the microfinance organisations subject to mainstream critique (Gordon, 2016). Whilst microfinance organisations predominantly provide services to women, previous studies have noted a dearth of women in leadership roles. For example, Hunt and Kasynathan's (2001) study, now dated, found that $70 \%$ of two microfinance organisations' staff were men. Rojiroti, however, is predominantly led by women from the communities in which it works, with women making up $80 \%$ of overall staff. Given the argument for the need to better understand the role of leadership in challenging inequalities (Batliwala, 2010; Jenkins, 2011), focusing on Rojiroti's women leaders may provide an important insight into whether they can engage with power relations that lead to inequality, and in doing so support social change.

Women living and working in their communities have long demonstrated their leadership in transforming power relations (Mwaura Muiru, Amati, \& Wamaitha Mbotela, 2012). However, others have noted that, while there are important and significant insights on the collective mobilisation of women as social actors, the role of leadership within grassroots groups is less examined (Subramaniam, 2011). Literature on leadership often focuses on access to formal leadership positions, so still too little is known about how women become leaders, particularly at the grassroots level (Domingo et al., 2015) and how grassroots women leaders contribute to social change. By drawing on feminist political ecology (FPE) and theories of transformative and feminist leadership, this article therefore seeks to extend the literature, by exploring women's leadership as part of a grassroots microfinance organisation in rural India. This article also seeks to contribute to policy discussions by determining in what ways interventions that seek to promote 'women's empowerment' can better support women to directly exercise power. Additionally, in sharing women's own perspectives on their leadership, and exploring whether leadership has contributed to social change, this article has relevance for those working in feminist movements that seek to effectively challenge inequality. To relate this study to the broader evidence on leadership, existing studies will firstly be explored.

\section{Exploring Women's Leadership}

Leadership is a contested concept, but overall involves mobilising people and resources, as well as navigating power relations (Domingo et al., 2015). However, in order to understand both what motivates leaders to initiate change, and how they do this, it is important to understand the way leaders interact with the world and the choices they are presented with, in this case as leaders of a grassroots microfinance organisation. Despite leadership being recognised as an important pathway to empowerment and social change, leadership in microfinance Self-Help Groups (SHGs) has been afforded little focus in the literature. One of the few studies exploring leadership within SHGs found that women who became group leaders were more likely to be younger, have higher education status, and be from better-off families than other group members (Singh, 2014); it also found that external influences, such as requirements for paperwork, often affected who was able to be a leader. Another study compared leadership in the Self-Employed Women's Association's (SEWA) which consists primarily of female union members, to the Grameen Bank, where there is more limited female leadership. Randleman (2013) argues that women leaders of SEWA enabled a more supportive infrastructure which enabled them to challenge power inequalities in the locations they worked. As limited attention has been given to the study of women's leadership within microfinance organisations, there is sparse evidence of the role of women's leadership within these organisations in supporting social change.

In place of a focus on leadership, the potential for SHGs to support social change has been explored in more depth. For example, studies have found that SHGs exposed women to new ways of thinking (Sanyal, 2009) and supported the recognition of shared interests (Janssens, 2010) which led some to challenge inequalities. More recently Kabeer, Narain, Arora, and Lal (2019) found that SHGs had provided a space in which women could develop consciousness and capabilities to take the lead on key issues, such as children's school attendance. As Kabeer (2011, p. 518) noted, membership of non-governmental organisations appeared "to be acting as a seedbed for grassroots leadership in the countryside." Broadly considered, grassroots leadership is a bottom up change process, led by actors outside of the dominant power structures which mobilises actors and resources for collective action (Subramaniam, Gupte, \& Mitra, 2003). For example, Subramaniam's (2011) study in rural India found that grassroots groups played 
an important role in facilitating consciousness-raising. Recently, Chaudhuri and Morash (2019) explored the work of a group of grassroots women leaders who were able to promote change by developing independent and innovative strategies of intervention that worked in spite of restrictive gender norms.

Therefore, the potential of women's groups to create supportive environments, that can develop consciousness and the direct exercise of power to achieve change is clear. However, further exploration of the role of women leaders within these groups could extend the literature on women's leadership, as many grassroots organisations that involve women's leadership tend to be small and localised and are thus rarely captured in the literature (Domingo et al., 2015). Focusing on Rojiroti's women leaders will also provide a contribution to the limited literature on leadership of microfinance organisations.

\subsection{Rojiroti Leadership}

Rojiroti is a grassroots microfinance organisation in the sense that it is community-based, relatively small in scope, and focuses on the issues that directly impact members' lives. As noted, microfinance has been strongly critiqued as an approach to women's empowerment. However, Rojiroti operates in distinct ways. When Rojiroti begins to operate in a new area, community mobilisers support women in joining SHGs. The focus then immediately shifts to supporting women members with an interest in, and aptitude for, facilitating groups to become the group leader. This approach has meant that Rojiroti is predominantly led by women, who also make up the majority of Rojiroti's managing board. As an organisation, it is neither entirely bureaucratically structured, nor entirely collectivist, but members are engaged in key decisions which indicates a distribution of authority. Feminist scholars have examined this form of hybrid group structure and leadership as contributing to the theoretical understandings of how collective action can facilitate consciousness-raising and lead to change in women's lives (Purkayastha \& Subramaniam, 2004).

Rojiroti operates in rural Bihar, where gender compounds with other structural factors such as class and caste, to inform social interactions (Govinda, 2008). More than 90 percent of Rojiroti members are from scheduled castes, tribes, or other disadvantaged castes. This is markedly different from other microfinance providers, with research indicating that just 20 percent of all microfinance members in India were from scheduled castes or tribes (Sa-Dahn, 2017). In this context leaders need to be able to understand the multiple forms of marginalisation that group members face, as it has been argued that in order for leaders to support social change, concepts and ideas need to be adapted to the cultural specificities of the social world in which women belong (Govinda, 2008).

Given the limited literature on leadership within microfinance organisations, Rojiroti provides an interest- ing example through which to explore women's leadership on a small scale, with potential to broaden understanding of how women's grassroots leadership can support social change. Additionally, it may provide insights for both microfinance organisations and policymakers who seek to contribute to 'women's empowerment' on how women's leadership might be an important aspect of tackling inequalities that constrain women's ability to directly exercise power. In order to explore the role of Rojiroti's women leaders in supporting social change, this article seeks to draw on insights from FPE and theories of transformative and feminist leadership.

\subsection{Theories of Feminist and Transformative Leadership}

Batliwala (2010) writes that leadership is first and foremost about holding, exercising and changing the distribution and relations of power. Feminist political ecologists suggest that gender is a crucial variable in understanding power, particularly in constituting access to, control over and knowledge of resources (Sundberg, 2017). FPE was forged out of feminist and women-centered scholarship and activism in environmental issues and was also informed by critiques of how women and other marginalised groups are excluded as knowledge holders. FPE has thus been vital in arguing for engaging women as political actors, and bearers and producers of knowledge; for example, Rocheleau and Edmunds (1997) highlighted that women in many rural areas manage spaces that are nested in, or between, spaces controlled by men. The ability of women to be recognised as agents of change is implicated within these power relations, and thus their perspective is vital in considering how to negotiate for social change. More recent FPE analyses have highlighted the importance of a focus on the intersections of power and oppression (Mollett \& Faria, 2013), making it clear that categories, such as class, ethnicity, caste and age, and subsequent power relations shape leadership. This provides the starting point from which to consider how leaders emerge, and how they contribute to social change.

In addition, the concept of transformative leadership, long associated with feminist leadership and motivated by equity and social justice (Antrobus, 2002), provides a useful lens for an analysis of the role of leadership in social change. A transformative feminist leader is understood as an individual who seeks to mobilise others around a shared agenda of transformation for equality, uses power to nurture people and build communities, leading through consultation, participation and consensus-building (Batliwala, 2010). This work on feminist leadership emphasises a dual concern, firstly with supporting women to take up leadership roles, which is shaped by gender and power dynamics (as highlighted by FPE), and also with them leading social transformation in ways that other forms of leadership do not and cannot. To explore both of these aspects, this article utilises an analytical approach to explore transformative and feminist leadership. 
Drawing on Batliwala's (2010) work, Wakefield's (2017, p. 35) framework identifies transformative and feminist leadership as: modelling feminist purpose and principles, setting an example and appreciating intersectionality; inspiring shared vision based on personal and collective reflexive learning; empowering and enabling others to act through building interpersonal relationships and trust; challenging patriarchal norms and oppressive power; and supporting the care and wellbeing of individuals and the group to contribute fully to transformation. This analytical approach is used to reflect on the actions of Rojiroti's women leaders.

\section{Methods}

The data for this article come from my PhD research, which sought to understand how membership of Rojiroti influenced women's financial, social and cultural resources, individual and collective agency and what effect this has had on girls' education. The research was underpinned by feminist standpoint epistemology and a commitment to knowledge building that centres and prioritises women's expertise and experiences (Hill Collins, 1990). The study was also guided by the commitment to research as being about "establishing, maintaining and nurturing reciprocal and respectful relationships" (Smith, 2013 , p. 129). My ongoing relationship with Rojiroti, for over four years at the time, was the starting point of this research, but I was positioned by my gender, age and ethnicity as an individual, but also part of a collective reality associated with histories of, and continuing, exploitation, including through research processes (Smith, 2013).

The responsibilities as a researcher therefore required being cognisant of power relations and seeking to be critically self-reflexive and transparent about these (Khatri \& Ozano, 2017). Throughout, communication with Rojiroti was important, asking them to contribute to, and question my decisions, to try and ensure that the methods were culturally sensitive and appropriate. This was important for considerations about informed consent and providing transparency about research decisions and likely outcomes with participants. In relation to exploring leadership, the nuances of intersubjectivity in the way in which I was able to interact with staff members and SHG members, is worth noting. For example, having existing relationships with women staff may have influenced their responses, as many of them reflected predominantly positively on their work; whilst I considered whether this was related to promotion of the organisation, they were generally not hesitant to share areas they could improve as a group. Although not related to their individual leadership, it implied they were willing to critically reflect. However, it is important to acknowledge that there may have been other aspects of their leadership which were not captured in this research. I have also sought to continually reflect on ethical considerations and challenges in more depth in other articles (Gordon, 2019).
Overall, the research consisted of eighteen one-onone interviews and thirty focus group discussions (FGDs). One-on-one interviews are an important way of gaining an understanding of the perspectives and motivations of those involved in the organisation in leadership roles, seeking insight into the way in which Rojiroti operates from the reflections of staff members. To foster discussions among those not involved in the leadership of the organisation, FGDs have been considered a good approach to hear multiple and collective voices (Liamputtong, 2015). The one-on-one interviews were conducted with seventeen women leaders from Rojiroti and one male staff member. As I did not want my preexisting relationship with Rojiroti to influence sampling, I randomly selected eighteen participants from the overall sample of all staff at the organisation; this was a large proportion of the overall staff number (31), so it sought to reduce bias, but maintain diversity and breadth of staff perspectives. The FGD sample came from a randomly selected list of fifty Rojiroti SHGs; again, this initial approach sought to reduce the risk of bias as I had engaged with many of its SHGs before. The thirty FGDs were then purposively selected based on the availability of members and to ensure that they represented the diversity of ages, geographical locations and number of years that groups had been in operation. All interviews and FGDs were recorded, translated and transcribed for analysis. The data were then analysed using thematic and inductive coding relating to the overall research questions.

During the inductive coding, a key theme that became clear was the important role Rojiroti's women leaders played in supporting social change (which was considered broadly to include any change in women's lives which they considered to be as a result of group membership, particularly shifts that challenged inequalities). Therefore, the coding of the data under this theme (from the seventeen interviews with women group leaders and all FGDs) is the main focus of the analysis for this article. Ongoing collaboration with Rojiroti also meant that I was able to follow up through informal discussions to explore women's role as leaders further with them. As a result, in addition to the main focus of the $\mathrm{PhD}$ research, the study also provided insight into gender and leadership in microfinance organisations. Also, in line with feminist standpoint epistemology, participants' emphasis on the importance of women's leadership warrants explicit focus in this article. Of note, this article does not seek to be generalisable; it provides an in-depth exploration on the role of women's leadership in a single organisation. However, it may offer insights of broader relevance about women's leadership at the grassroots level.

\section{Where Do Leaders Come From?}

Leaders are always situated in a particular context. In this case, many women's route into leadership came through 
joining SHGs that Rojiroti operated, inherently linking leadership to their motivation to join these groups. This focused mainly on their perception that joining Rojiroti could provide positive opportunities for themselves and their families: "I shed the purdah and joined this group for the sake of my children" (Rojiroti Group Leader, Interview \#15). One woman explained how she was motivated to lead groups to improve her own skills, and the skills of her family and community. Women also saw the role of leadership as enabling them to gain desired independence: "Earlier I was confined to my home, now I have the freedom to move and go out for work" (Rojiroti Group Leader, Interview \#4); "Women were not allowed to step outside of their homes, and they could never even think about working.... am part of this group now, and I have reached up to the level of overall treasurer" (Rojiroti Group Leader, Interview \#2). "Because of this exposure I can work in the school and have gained status in the family and society" (Rojiroti Group Leader, Interview \#16). Feminist political ecologists have often highlighted how women's lack of access to resources, as a result of gendered power relations within their community, restricts their ability to access income-generating opportunities that support their independence (Sundberg, 2017). In this context, patriarchal social norms and practices place women in a situation of dependence on male relations, who become the central conduit for access to resources (Agarwal, 2003). Women were motivated towards leadership by an opportunity that subverted these power-laden practices and relations, and enabled access to resources, and subsequently increased independence.

In the informal follow up conversations with Rojiroti staff about their motivations for taking up leadership positions, women also noted how they had taken these roles because it was easier for women to reach and connect with other women: "They will get more information if there are women leaders" (Rojiroti Group Leader, Interview, \#2). They emphasised the importance of their own identity in being able to better set up, support and share information with women. Many of them saw a leadership role as one of responsibility to others around them: "there is affection among group members...we have become family" (Rojiroti Group Leader, Interview, \#1). As noted in the literature "group action can be vital in supporting women's self-esteem and selfconfidence" (Evans \& Nambiar, 2013, p. 4); in this case the experience of being in close relationships with other women appeared to build their sense of purpose and confidence in their ability to act as leaders, and they were motivated to support group members by taking on these positions. A FPE perspective, which focuses on the social relations surrounding who accesses services and resources, and how access is achieved, would argue that "women's place-based politics is embedded in, rather than removed from the material lives they are trying to change" (Harcourt \& Escobar, 2002, p. 11). Thus, taking up leadership roles could represent a rein- vention of practices and possibilities, whereby women previously excluded from access to power could become a conduit through which to transfer it to other women in their communities.

Wakefield's (2017) framework notes that women investing in structures, processes and practices that disable patriarchal norms is an important part of transformative feminist leadership. Rojiroti women leaders had noted that many other microfinance organisations operating in their area had male staff; by becoming leaders, women were dismantling the place-based norm of men's leadership of similar organisations. Women's perspective on their own drive to take up leadership positions, to provide this close-knit form of leadership, may also be seen as a reaction to this patriarchal norm through its role in challenging power structures which influenced access to opportunities and resources for women. Women's reflections on the way in which they felt confident in these roles also reflects on this change in practice and possibilities: "I might have grown older age wise, but I feel much younger and more energetic because of Rojiroti. I have learnt communication and social skills and have started questioning and debating too" (Rojiroti Group Leader, Interview \#6). Another Rojiroti group leader reflected on her leadership skill development: "Due to the meetings and the visits of different places, I want to visit new places to learn more and to see new things. It gives me confidence and exposure" (Rojiroti Group Leader, Interview \#14). Women's leadership is thus fluid, operating within existing networks, but also creating new networks and opportunities which have the potential to challenge unequal power dynamics. However, whilst it is clear women leaders were motivated by this opportunity to provide alternative approaches to accessing resources for other women, it is also important to explore whether their leadership was able to contribute to social change (Batliwala, 2010).

\section{Do Rojiroti Leaders Demonstrate Transformative Leadership and Support Social Change?}

Findings showed that Rojiroti women staff often lead their groups in ways that could contribute to challenging inequitable social structures in three main ways: by supporting relationship building within the SHGs, by facilitating knowledge transfer and by creating space for reflection and skills for action.

\subsection{Leadership as Relationship Building}

The FGDs highlighted the fact that group leaders do not just come to deliver loans and leave. Rojiroti group leaders provided emotional and social support, as summarised by two group members, "we became close to each other during the formation of the group" (FGD, Interview \#29); "During group meetings we come closer to each other and discuss many things which increases our awareness" (FGD, Interview \#25). Group leaders 
also agreed that "the social aspects of meeting helps us in bonding and providing solutions for fellow members." (Rojiroti Group Leader, Interview \#8);

Other groups are limited to finance and they have no concern about social or emotional values of their members. Their relationship is solely of borrower and lender. However, with Rojiroti, we are helped to grow as a person, as the group understands our emotions. (Rojiroti Group Leader, Interview \#20)

In providing leadership that went beyond enabling access to resources, Rojiroti women leaders were actively building relationships between themselves and group members, and among group members. Wakefield (2017) emphasises building interpersonal relationships and providing space to help people to connect on a personal level as being important aspects of transformative leadership.

This relationship building was recognised as having been fundamental to group solidarity in an example given by one of Rojiroti's group leaders:

The sudden death of my daughter had a very negative impact on my mental health....They (other group members) took me up to the hospital and provided monetary help in my hour of need. I got all support from them, which is the benefit of the group. (Rojiroti Group Leader, Interview \#18)

Another group leader highlighted this point too:

We discuss almost everything, and meetings help us to bond and understand each other. We also share our family problems and social issues. We also share lighter moments and have fun. In short, these meetings are quality time for us. (Rojiroti Group Leader, Interview \#13)

These examples relate strongly to Wakefield's (2017) observation that through building interpersonal relationships, transformative leaders support the care and wellbeing of individuals and groups. This can strengthen the ability of women to stay connected and resilient in the face of stress, which is vital to contributing to social change through collective action.

FPE underscores the importance of situated knowledge, and relationality (Elmhirst, 2015), which is important for understanding how Rojiroti's women leaders were particularly able to build relationships among their SHG members. When microfinance organisations channel leadership that is predominantly male, and often from outside the communities they seek to represent, this is likely to reinforce power dynamics as to who has control over resources. Fewer shared lived experiences may also inhibit deep connections or leader's ability to understand how to support the care and well-being of individuals and groups. As one member noted: "Lady can understand the problems of another lady better, it doesn't matter from where she belongs....We are associated with this group due to Madam's [Rojiroti group leader] good nature" (FGD, Interview \#26). Rojiroti leaders also felt that their identity was an important part of their role as a leader: "we belong to the same social group, same language and same culture" (Rojiroti Group Leader, Interview \#2). Although ages varied among group leaders and group members, Rojiroti's women leaders could understand experiences of marginalisation related to gender and were similarly positioned by other experiences of marginalisation related to class and caste. Previous research has noted that a lack of attention to caste and class differences in microfinance organisations, and a lack of trust in leadership and poor communication among organisations, may impede a group from acting collectively for change (Lahiri-Dutt \& Samanta, 2006); therefore, the relationships that Rojiroti women leaders were able to nurture, which led to affinity between themselves and group members, appeared to represent a form of leadership that challenged, rather than replicated unequal and unsupportive group dynamics.

Related to Wakefield's (2017) framework, an appreciation and an understanding of the intersection of social categories, and how they connect to social justice challenges and solutions is an important component of transformative leadership. Acting from this knowledge and understanding strengthened Rojiroti women leaders' ability to build and encourage strong relationships that support individuals and groups and is essential to the wider political processes required for transformation. However, with any focus on leadership and its potential to effect transformative change, even in circumstances where strong relationships are built, the power dynamics between leaders and groups must be considered and solidarity requires an active engagement with power dynamics (Sangtin Writers \& Nagar, 2006). Thus, the above quotation "We are associated with this group due to Madam's [Rojiroti group leader] good nature" must be reflected upon. For any person to be associated with a helpful resource as a result of someone's good nature (rather than because it is their right) has the potential to replicate, rather than challenge, existing power relations, even if women come from the same social groups. Therefore, while the potential for social change through relationship building is apparent, more interrogation is needed about whether it materialises.

\subsection{Leadership as Supporting Knowledge Transfer}

As noted elsewhere, leaders' support to build skills and information has the potential to challenge inequitable structures (Subramaniam, 2011). Transformative leadership is based on a radical learning tradition where information and knowledge are an important part of the processes of empowerment and collective action (Blackwell, 2006). The direct role of Rojiroti's women leaders in supporting knowledge transfer was noted by numerous 
SHG members in one FGD: "We were not even able to sign, but after formation of the group...our coordinator encouraged us to learn how to sign"; "After joining the group, all the wisdom opened up. We did not know how to sign, but didi [Rojiroti group leader] taught us how to sign. We learnt the way to talk to someone." Later in that same group: "Initially, not so many people come to us while we attended the group meeting, but now many people come to us, we talk to them and this increases our knowledge and understanding" (FGD, Interview \#27). In another group, one member noted of the group leader: "Whenever she comes, she tells us some new things, so our level of understanding increases" (FGD, Interview \#3). Multiple group leaders also explained how they shared knowledge on practical issues: "We also tell them about financial literacy, how to calculate rate of interest etc." (Rojiroti Group Leader, Interview \#8). One leader gave examples of a range of information shared: "I helped members to open up their saving bank account and I have given advice to them about doctors and hospital" (Rojiroti Group Leader, Interview \#10). The potential of sharing knowledge and information is linked to Wakefield's (2017) consideration that transformative leadership should challenge existing inequalities, in order to empower and enable others to act. In this context, where group members may not have had access to formal education opportunities, in part influenced by social norms that impact on the value given to women's education (Singh \& Mukherjee, 2018), leaders supporting learning is directly addressing discrimination and marginalisation.

Knowledge transfer was not only limited to information about practical skills. In line with a transformative approach to leadership, that illuminates the invisible structures and systems which serve to perpetuate and normalise domination and oppression (Wakefield \& Zimmerman, 2020), Rojiroti group leaders spoke of their role in challenging barriers to gender equality:

In the group, I discuss about many things, it is not only about making receipts for loans, members have learnt to calculate their loans and interest on it. I discuss about their children's education, marriage etc. Social awareness is created, and we discourage child marriage or early marriage, for example. (Rojiroti Group Leader, Interview \#1)

Related to Rojiroti women leaders' ability to build relationships, their strategies to challenge inequalities are informed by their own personal experience and situated knowledge of challenging conventional practices and discrimination in the face of similar barriers. In the transformational leadership literature, leaders who are able to inspire others to reflect on the way they do things, and to provide ways to challenge gendered norms, are more likely to achieve social change (Wakefield, 2017).

One SHG member provides an example of how knowledge supported women to fight for girls' right to edu- cation: "Earlier girls were exploited through domestic violence, dowry or for other things. They were forced to bring dowry. Education is being provided so that they can fight for their rights." Later in this same group, "Now no one dare exploit as girls get knowledge so that they can fight against exploitation" (FGD, Interview \#20). Transformative and feminist leaders use tools and processes to surface harmful expressions of power within institutions (Wakefield, 2017); in this case, access to knowledge was considered to be crucial in enabling challenges to oppressive power. In previous studies of women's grassroots leadership, knowledge transfer has not always been an active part of women's grassroots leadership (Barrig, 1996). In direct contrast, Rojiroti women leaders actively sought to share skills, ideas and information, which appeared vital in supporting women to develop the necessary capabilities to contest power dynamics (Das \& Dasgupta, 2013).

Inspiring shared vision, through individual and collective reflexive learning and unlearning, another key attribute of transformative leadership (Wakefield, 2017), was also clear through discussions about women leaders being role models. FGDs suggested that interaction with group leaders had led to shifting perspectives about girls' education:

We have already said that when they [daughters] see us attending the meeting, they get inspired. They see she [Rojiroti group leader] comes to lead the meetings, so we tell them that she leads the meeting because she is educated. (FGD, Interview \#20)

Rojiroti leaders also considered the role model effect that their leadership of SHGs could have on changing perspectives on girls' education: "We, the working women of Rojiroti, are role models for educating girls" (Rojiroti Group Leader, Interview \#10). FPE has consistently challenged essentialist notions of identity, arguing that the symbolic meanings of place, practices and bodies are (re)produced through everyday activities (Nightingale, 2011). It could be argued that Rojiroti women leaders may have begun to challenge the boundaries of restricted behaviour. As gender is constructed, it can also be reconstructed through people's everyday practices (Elmhirst, 2015), such as when women who previously have not been in positions of leadership take up these roles. Using Ray's (2006) theory of aspiration building, the window of aspiration is formed by a zone of similar, attainable individuals; therefore, the fact that Rojiroti's women leaders come from similar social groups is likely linked to their ability to inspire shared vision, through their example of the potential that social change could have.

\subsection{Leadership that Creates Space for Reflection and Skills for Action}

As well as transformative leaders promoting collective learning and inspiring shared vision, Wakefield's 
(2017) framework emphasises the importance of leaders empowering and enabling others to act, often as a result of processes of self-reflection. As one Rojiroti group leader explained: "I listen to all of the members' problems and discuss the solutions within the group...life is changing because women are becoming aware and independent" (Rojiroti Group Leader, Interview \#7). This is often explicitly about raising awareness on areas of discrimination: "I counsel the members and make them more aware about their rights and social behaviour, transferring the skills of the debating for women in their household. I believe in division of work in the household, so I share this" (Rojiroti Group Leader, Interview \#6). This is an important part of consciousness raising as it enables better understanding of gender-specific constraints in women's lives, as well as how to tackle them (Subramaniam, 2006; 2011), demonstrating the link between leadership and potential social change. In this example, the less tangible aspects of transformative leadership, namely nurturing relationships (Wakefield \& Zimmerman, 2020), supported the development of a safe space for reflection and skill development.

There is extensive information about SHGs leading to women feeling more confident and being able to speak out. This is also associated with the literature on women's organisations (see Section 2) and is often related to the fact that SHGs provide spaces for dialogue and collaboration through "ongoing processes of learning, reflection, action, experience, observation and analysis" (Kabeer, 2011, p. 511). In line with this evidence, one of the Rojiroti group leaders considered how these spaces had enabled the challenging of existing power relations: "They can speak their mind now, whereas earlier it was not possible for a woman to share her views.... Rojiroti has helped me and other members to support their families and becoming aware about things" (Rojiroti Group Leader, Interview \#16). However, to be able to create a space where women can analyse their shared experiences of injustice and oppression in a way that empowers and enables them to act to challenge it requires leadership which fosters trust among group members.

Reflections from FGDs suggested that Rojiroti group leaders ensured that power was diffused within their groups, particularly encouraging collective leadership. For example, although Rojiroti group leaders facilitate meetings, they are organised by members and decisionmaking is shared:

In our group, we fix the time while in other groups, the coordinator fixes the time. Here we say to our group leader to come as per our convenience. Suppose we have to go harvest paddy, we would call her earlier. At the time of sowing saplings, we call her early in the morning, but at the time of collecting grains from the harvested crops we call her at noon. (FGD, Interview \#4)
Rojiroti group leaders play a facilitative leadership role that supports women to connect, interact and actively engage in leadership as a group. As noted in another group "when all of us sign the paper, only then is the loan approved....We take decisions with mutual consent" (FGD, Interview \#27). The ability to share their perspective in an environment where leadership prioritised the power for group members to participate on an equal basis, appears to have built up trust and the potential to create spaces of openness where resistance can be cultivated (Wakefield, 2017).

Examples of how dialogue and reflection in groups led to the development of skills for action were also given, as one group member explained: "Here (in group meetings) debate takes place where we learn.....It also gives financial literacy which helps us in discussing with male counterparts at home" (FGD, Interview \#8). One member explained how these spaces had enabled her to challenge her husband's lack of support for their daughters' continuing education:

My husband has said that they did not need higher education and he was opposing me, as he said that if she attained PG level degree, then education required for our son-in-law will be higher, but I am able to make more persuasive argument now since Rojiroti. (FGD, Interview \#11)

These examples provide evidence of how Rojiroti group leaders demonstrated transformative leadership, through ensuring collective structures that developed women's skills in safe spaces of dialogue and reflection, which led to them actively challenge unequal power structures (Wakefield, 2017).

Noted less often in other studies is how women's organisations in this context build these skills among members, who go on to access to formal political positions. It appears that these spaces, where women had the opportunity to share life experiences, seek solutions to common problems, and practise diffused leadership, may have supported building women into "communities of practice" that facilitated their "struggles in the political domain" (Kabeer, 2011, pp. 513-514). For example, the confidence and skills members gained through their participation in diffused Rojiroti leadership structures led to them standing for more formal leadership positions:

We get knowledge by discussing on problems and solution with each other. We did not know the name of each women prior to joining Rojiroti and now by sitting in the groups, we know each other by name also. I am representative of Panchayat Raj [local government]. (FGD, Interview \#24)

Another woman in this group reflected on the importance of these spaces for improving confidence in their leadership, as well as developing practical ways 
in which demands for change could be made: "With Rojiroti we are stronger at Panchayat.... am ward member for last three years and have learnt how to influence Panchayat....I prepare strategies to put forward our demands" (FGD, Interview \#24). The collective leadership fostered by Rojiroti group leaders has led to the energising relationships that Wakefield (2017) considered vital for thriving transformative leadership. Although the exact changes women were making in these formal leadership roles were not mentioned, their ability to access these roles, which may not have been possible previously, indicates social change in itself.

\section{Conclusion}

Overall, this article's exploration of women's leadership within one grassroots microfinance organisation illustrates the importance of grassroots women leaders, who are able to organise around issues actively and address multiple forms of oppression in the process (Subramaniam, 2011). Driven by a strong sense of responsibility to those around them, and their recognition that taking up these roles could provide greater independence and opportunities, the ways in which Rojiroti's leaders worked were in line with understandings of transformative leadership (Wakefield, 2017). Drawing on data from seventeen interviews and thirty FGDs, this study extends the literature through its exploration of how grassroots women leaders took forward feminist and transformative leadership approaches to support social change. Analysis underscored by FPE highlighted that women's situated knowledge was particularly important for building strong relationships, supporting care and well-being of group members, and creating safe spaces for personal and collective reflexive learning which inspired shared vision and strategies for challenging of unequal structures.

These findings also highlight the attention that policymakers must pay to the ways in which programmes or services are designed, and the crucial role of women's leadership within them to avoid depoliticised, and ultimately harmful, approaches to empowerment. By taking on leadership roles, it appeared that Rojiroti's women leaders had been able to reconstruct ideas around gender roles and leadership which, combined with diffused and collective decision-making and skill development, challenged, rather than perpetuated existing inequalities. The space for dialogue and reflection, in an environment where leadership fostered trust and encouraged group members to participate on an equal basis also opened up opportunities for more women to lead. As recently argued by Wakefield and Zimmerman (2020), learning from this form of leadership that nurtures relationships and cultivates new approaches to decision making and action is critical to the current challenges facing sustainable and equal development and therefore these findings may also be relevant to activists mobilising to challenge inequality.

\section{Acknowledgments}

I am grateful for the support of Rojiroti throughout my $\mathrm{PhD}$, and for the knowledge and insights shared that has supported this analysis from Rojiroti's women leaders, including those who participated in one-on-one interviews: Ajmeri Khatun, Amrita Kumari, Gyanti Devi, Kanti Devi, Kiran Devi, Nilam Devi (Pirhi), Nilam Devi (Alipur), Nirasha Devi, Nirmala Devi, Pratibha Kumari, Pratima Devi, Punam Devi, Rinku Devi, Rita Devi, Savitri Devi, Smida Khatun, Sudha Devi, Sunita Devi, Sunayana Devi, Surana Devi and Suraykanti Devi. I am also grateful to Rojiroti's other staff members, in particular Sunil Choudhary for support and guidance during this research and for those who supported the practicalities of the research process. I am also grateful to the critical friends who reviewed this piece and to the three reviewers for their extremely helpful feedback. This research was completed whilst I was a PhD student at the Faculty of Education, University of Cambridge, but the paper was written after I completed my PhD.

\section{Conflict of Interests}

The author declares no conflict of interests.

\section{References}

Agarwal, B. (2003). Gender and land rights revisited: Exploring new prospects via the state, family and market. Journal of Agrarian Change, 3(1/2), 184-224.

Antrobus, P. (2002). Feminism as transformational politics: Towards possibilities for another world. Society for International Development, 45(2), 46-52.

Barrig, M. (1996). Women, collective kitchens and the crisis of the state in Peru. In J. Friedmann, R. Abers, \& L. Autler (Eds.), Emergences: Women's struggles for livelihood in Latin America. Pittsburgh, PA: Latin American Center Publications.

Batliwala, S. (2007). Taking the power out of empowerment: An experiential account. Development in Practice, 17(4/5), 557-565.

Batliwala, S. (2010). Feminist leadership for social transformation. New Delhi: Creating Resources for Empowerment in Action.

Blackwell, M. (2006, June 1). Farmworker women's organising and gendered grassroots leadership. UCLA Center for the Study of Women. Retrieved from https://escholarship.org/content/qt9bq9k752/ qt9bq9k752.pdf

Chant, S. (2016). Women, girls and world poverty: Empowerment, equality or essentialism? International Development Planning Review, 38(1), 1-24.

Chaudhuri, S., \& Morash, M. (2019). Building empowerment, resisting patriarchy: Understanding intervention against domestic violence among grassroots women in Gujarat, India. Sociology of Development, 5(4), 360-380. 
Das, A., \& Dasgupta, J. (Eds.). (2013). Claiming entitlements: The story of women leaders' struggle for the right to health in Uttar Pradesh, India. New Delhi: Centre for Health and Social Justice and Community of Practitioners on Accountability and Social Action in Health.

Domingo, P., Holmes, R., O'Neil, T., Jones, N., Bird, K., Larson, A., Presler-Marshall, E., \& Valters, C. (2015). Women's voice and leadership in decision-making. London: Overseas Development Institute.

Elmhirst, R. (2015). Feminist political ecology. In T. Perrault, G. Bridge, \& J. McCarthy (Eds.), The Routledge handbook of political ecology (pp. 519-530). London: Routledge.

Esquivel, V., \& Sweetman, C. (2016). Gender and the sustainable development goals. Gender \& Development, 24(1), 1-8.

Evans, A., \& Nambiar, D. (2013). Collective action and women's agency: A background paper. Washington, DC: World Bank.

Gordon, R. (2016). Succeeded where others have failed? Has Rojiroti's model of microfinance led to reduction in domestic violence? Enterprise Development and Microfinance, 27(3), 173-191.

Gordon, R. (2019). 'Why would I want to be anonymous?' Questioning ethical principles of anonymity in crosscultural feminist research. Gender \& Development, 27(3), 541-554.

Govinda, R. (2008). Re-inventing Dalit women's identity? Dynamics of social activism and electoral politics in rural north India. Contemporary South Asia, 16(4), 427-440.

Harcourt, W., \& Escobar, A. (2002). Women and the politics of place. Development, 45, 7-14.

Hill Collins, P. (1990). Black feminist thought: Knowledge, consciousness and the politics of empowerment. New York, NY: Routledge.

Hunt, J., \& Kasynathan, N. (2001). Pathways to empowerment: Reflections on microfinance and transformation in gender relations in South Asia. Gender and Development, 9(1), 42-53.

Janssens, W. (2010). Women's empowerment and the creation of social capital in Indian villages. World Development, 38(7), 974-988.

Jenkins, K. (2011). Depoliticisation and the changing trajectories of grassroots women's leadership in Peru: From empowerment to service delivery? Journal of Latin American Studies, 43, 299-326.

Kabeer, N., (2005). Is microfinance a 'magic bullet' for women's empowerment? Analysis of findings from South Asia. Economic and Political Weekly, 40(44), 4709-4718.

Kabeer, N. (2011). Between affiliation and autonomy: Navigating pathways of women's empowerment and gender justice in rural Bangladesh. Development and Change, 42(2), 499-528.

Kabeer, N., Narain, N., Arora, V., \& Lal, V. (2019). Group rights and gender justice: Exploring tensions within an indigenous community in India (Working Paper No. 33). London: LSE International Inequalities Institute.

Khatri, R. J., \& Ozano, K. A. (2017). Reflexivity, positionality and power in cross-cultural participatory action research with research assistants in rural Cambodia. Educational Action Research, 26(2), 190-204.

Lahiri-Dutt, K., \& Samanta, G. (2006). Constructing social capital: Self-help groups and rural women's development in India. Geographical Research, 44(3), 285-295.

Liamputtong, P. (2015). Focus group methodology in cross-cultural research. Thousand Oaks, CA: Sage.

Mollett, S., \& Faria, C. (2013). Messing with gender in feminist political ecology. Geoforum, 45, 116-125.

Mwaura Muiru, E., Amati, J., \& Wamaitha Mbotela, A. (2012). The 'champions for transformative leadership' initiative: Kenyan grassroots women as agents of change. Universitas Forum, 3(1), 1-13.

Nazneen, S., Hossain, N., \& Chopra, D. (2019). Introduction: Contentious women's empowerment in South Asia. Contemporary South Asia, 27(4), 457-470.

Nightingale, A. J. (2011). Bounding difference: Intersectionality and the material production of gender, caste, class and environment in Nepal. Geoforum, 42(2), 153-162.

Pokhriyal, A., Rani, R., \& Uniyal, J. (2014). Role of microfinance in the empowerment of the women. Journal of Business and Finance, 2(1), 21-31.

Purkayastha, B., \& Subramaniam, M. (Eds.). (2004). The power of women's informal networks: Lessons in social change from South Asia and West Africa. Lanham, MD: Lexington Press.

Randleman, R. M. (2013). Women as leaders in differing microfinance models. Journal of Interdisciplinary Feminist Thought, 7(1), Article 3, pp. 1-18.

Ray, D. (2006). Aspirations, poverty and economic change. In V. Banerjee, R. Benabou, \& D. Mookherjee (Eds.), Understanding poverty (pp. 409-422). Oxford: Oxford University Press.

Rocheleau, D., \& Edmunds, D. (1997). Women, men and trees: Gender, power and property in forest and agrarian landscapes. World Development, 25(8), 1351-1371.

Sa-Dahn. (2017). The Bharat microfinance report 2017. New Delhi: Sa-Dahn.

Sangtin Writers, \& Nagar, R. (2006). Playing with fire: Feminist thought and activism through seven lives in India. Minneapolis, MN: University of Minnesota Press.

Sanyal, P. (2009). From credit to collective action: The role of microfinance in promoting women's social capital and normative influence. American Sociological Review, 74, 529-550.

Singh, A. (2014). Leadership in female SHGs: Traits/ abilities, situational or forced? International Journal of Sociology and Social Policy, 34(3/4), 247-262.

Singh, R., \& Mukherjee, P. (2018). Whatever she may 
study, she can't escape from washing dishes': Gender inequality in secondary education-Evidence from a longitudinal study in India. COMPARE, 48(2), 262-280.

Smith, L. T. (2013). Decolonizing methodologies. London: Zed Books.

Subramaniam, M. (2006). The power of women's organising: Gender, caste, and class in India. Landham, MD: Lexington Books.

Subramaniam, M. (2011). Grassroots groups and poor women's empowerment in rural India. International Sociology, 21(1), 72-95.

Subramaniam, M., Gupte, M., \& Mitra, D. (2003). Local to global: Transnational networks and Indian women's grassroots organising. Mobilisation, 8(2), 253-270.

Sundberg, J. (2017). Feminist political ecology. In D. Richardson (Ed.), The international encyclopaedia of geography. Hoboken, NJ:Wiley Online.

Wakefield, S. (2017). Transformative and feminist leadership for women's rights. Boston, MA: Oxfam America.

Wakefield, S., \& Zimmerman, K. (2020). Re-imagining resilience: Supporting feminist women to lead development with transformative practice. Gender and Development, 28(1), 155-174.

Wilson, K. (2015). Towards a radical re-appropriation: Gender, development and neoliberal feminism. Development and Change, 46(4), 803-832.

\section{About the Author}

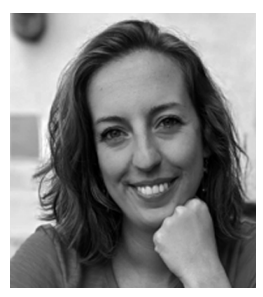

Rebecca Gordon recently completed her PhD, which explored the work of a grassroots microfinance organisation and long-term impacts on girls' education. She is currently a Research Fellow in Leadership for Inclusive and Democratic Politics. 